\title{
« The Political Climate in Nineteenth Century Iran; The Early Political Career of Hosein Qolī Khān-e Māfī ». Bulletin of the Society for Near Eastern Studies in Japan, 45-1(2002), pp. 172-190 [in Japanese].
}

\section{Akihiko Yamaguchi}

\section{(2) OpenEdition}

\section{Journals}

Édition électronique

URL : http://journals.openedition.org/abstractairanica/5975

DOI : 10.4000/abstractairanica. 5975

ISSN : 1961-960X

Éditeur :

CNRS (UMR 7528 Mondes iraniens et indiens), Éditions de l'IFRI

Édition imprimée

Date de publication : 15 mai 2006

ISSN : 0240-8910

\section{Référence électronique}

Akihiko Yamaguchi, « «The Political Climate in Nineteenth Century Iran; The Early Political Career of Hosein Qolī Khān-e Māfi ». Bulletin of the Society for Near Eastern Studies in Japan, 45-1(2002), pp.

172-190 [in Japanese]. », Abstracta Iranica [En ligne], Volume 27 | 2006, document 178, mis en ligne le 02 janvier 2007, consulté le 25 septembre 2020. URL : http://journals.openedition.org/ abstractairanica/5975 ; DOI : https://doi.org/10.4000/abstractairanica.5975

Ce document a été généré automatiquement le 25 septembre 2020.

Tous droits réservés 
« The Political Climate in Nineteenth Century Iran; The Early Political Career of Hosein Qolī Khāne Māfī ». Bulletin of the Society for Near Eastern Studies in Japan, 45-1(2002), pp. 172-190 [in

\section{Japanese].}

Akihiko Yamaguchi

1 This paper describes in detail how a man of modest origin could raise himself to a prominent position in the Qajar political milieu. The early career of Hosein Qolì Hān-e Māfĩ (1832/3-1908) is discussed here. Analyzing his memoirs, Hâterât va Asnâd-e Hosein Qolī Hुān Nez̧âm al-Salțaneh-ye Māfi, edited by Ma'șumeh Ettehāaidieh et al., $2^{\text {nd }}$ ed., Teheran, 1362/1983-4, the author argues that, serving Solțān Morād Mīrzā Ḥesām alSalțaneh (1818-1883), Ḥosein Qolī Hān did not only become quite experienced in administrative works, but also learned to act with great tact among men of power.

INDEX

Thèmes : 4.2.1. Safavides et Qâjârs 


\section{AUTEURS}

AKIHIKO YAMAGUCHI

University of Sacred Heart - Tokyo 